3. Власов, А. В., Жикривецкая, Ю. В. Некоторые аспекты виктимности в динамической концепции преступности и преступного поведения // Вестник ГУУ. 2017. №1. URL: https://cyberleninka.ru/article/n/nekotorye-aspekty-viktimnosti-v-dinamicheskoy-kontseptsiiprestupnosti-i-prestupnogo-povedeniya (дата обращения: 14.05.2020).

4. Карпец, И. И. Уголовное право и этика / И.И. Карпец. - М.: Юридическая литература, 2016. - С. 127.

5. Козаченко, И. Я. Уголовное право. Общая часть / И.Я. Козаченко, Г.П. Новоселов. - М.: Юрайт, 2019. - С. 254.

\title{
Шабунько Ю.А. \\ Проблемы приватизация земельных участков , находящихся в границах национальных парков
}

ФГБОУ ВО «Кубанский государственный аграрный университет имени И. Т. Трубилина»

(Россия, Краснодар)

doi: 10.18411/lj-05-2021-208

\section{Аннотация}

В представленной научной статье исследована одна из актуальных проблем земельного права, касающаяся изменений действующего законодательства Российской Федерации, в частности, преобразований связанный с возможностью отчуждения земельных участков, размещенных в границах населенных пунктов, введенных в состав национальных парков. При этом некоторые положения законодательства, касающиеся данного вопроса остались неизменными, что несомненно влечет к определенным трудностям введения их в действие как для правоприменителя, так и для граждан, проживающих на данной территории.

Ключевые слова : особо охраняемые природные территории, национальный парк, приватизация, изменения земельного законодательства, совершенствование природоохранного законодательства.

\section{Abstract}

The presented scientific article examines one of the current problems of land law, concerning changes in the current legislation of the Russian Federation, in particular, related to the possibility of alienation of land plots located within the boundaries of settlements included in national parks. At the same time, some provisions of the legislation relating to this issue have remained unchanged, which undoubtedly leads to certain difficulties in putting them into effect both for the law enforcement officer and for citizens living in this territory.

Keywords: specially protected natural territories, national park, privatization, changes in land legislation, improvement of environmental legislation.

В Российской Федерации насчитывается около 62 национальных парков, в составе которых находятся населенные пункты с количеством проживающих в нем граждан превышающих 380 тысяч людей.

Глава комитета Совета Федерации Российской Федерации по природопользованию А. Майоров в своих выступлениях не раз обращал внимание на то ,что правовой статус земель национальных парков ограничивает демократические права граждан, которые проживают на данных территориях.

Земли национальных парков согласно законодательству являются землями особо охраняемых природных территорий , в связи с чем на них распространяется множество запретов и ограничений.

Одним из таких ограничений является прямой запрет на приватизацию данных земель, а также запрет на предоставление на территориях национальных парков 
земельных участков для ведения садоводства и огородничества, индивидуального гаражного или индивидуального жилищного строительства.

Соответственно, действующее до настоящего времени положение данных земель существенно ограничивало конституционные права граждан, в связи с чем, законодатель пришел к выводу об улучшении данного положения граждан.

В Государственную Думу 17 июня 2020 года был внесен законопроект, а 30 декабря 2020 года принят, который полностью затрагивал регулирование вопроса отчуждения земельного участка, расположенного в границе населенного пункта , который включен в состав национальных парков.

В данном законопроекте были изложены положения о внесении соответствующих изменений в законодательство, в частности , касающихся возможности передачи данных земельных участков как в собственность субъектов Российской Федерации и муниципалитета, так и в собственность юридических лиц и граждан, последние в свою очередь получили право заниматься некоторой деятельностью на своем земельном участке, без нарушения законодательства, которая ранее была под запретом, а именно добыча подземных вод, их разведка; заготовка и сбор лесных ресурсов ,а также садоводство и огородничество.

Говоря о данной возможности приватизации земельного участка, находящегося в границах национальных парков, то согласно Градостроительному Кодексу Российской Федерации приватизация будет возможна только при одновременном соблюдении определенных условий, а конкретно:

1. Существование населенного пункта до создания на нем национального парка;

2. Границы данных территорий не пересекаются с границами, находящимися вне территорий;

3. Сведения о таких участках обязательно должны быть внесены в Единый Государственный Реестр Недвижимости.

Таким образом, появилась возможность оформления земельных отношений в области приватизации земельных участков, находящихся на территории национальных парков.

Изменения коснулись как Федерального закона от 14 марта 1995 года № 33-Ф3 «Об особо охраняемых природных территориях» и «Земельного Кодекса Российской Федерации» от 25.10.2001 N 136-Ф3 (ред. от 30.12.2020) (с изм. и доп., вступ. в силу с 10.01.2021), так и таких законодательных актов, как:

— Федерального закона от 23 ноября 1995 года № 174-Ф3 «Об экологической экспертизе»,

— «Градостроительного кодекса Российской Федерации» от 29.12.2004 N 190-ФЗ (ред. от 30.12.2020) (с изм. и доп., вступ. в силу с 10.01.2021),

- Федерального закона от 13 июля 2015 года № 218-Ф3 «О государственной регистрации недвижимости».

Соответственно, можно сделать вывод исходя из того, что данные изменения затронули широкий круг законодательных актов, то они должны достаточно подробно урегулировать данные нововведения. Но не все аспекты были достаточно полно раскрыты, поэтому на них также необходимо обратить внимание.

В частности, одна из проблем касается существования населенного пункта до появления национального парка, поскольку законодатель не дает конкретной и полной информации о дате создания таких населенных пунктов.

Для восполнения данного пробела требуется уточнение данной информации для избежания притеснений прав граждан , которые проживают непосредственно на данной территории. 
Положение данного закона по вопросу не пересечения границ населенного пункта с границами вне участков, расположенных под национальные парки также не учитывает положения норм о внесении в Единый государственный реестр недвижимости сведений о границах населенных пунктов и национальных парков , регулируемых статьей 34 Федерального Закона «О государственной регистрации недвижимости» .

Законодатель также не учел положения пункта 8 статьи 28 Федерального закона «О приватизации государственного и муниципального имущества» от 21.12.2001 N 178-Ф3 (ред. от 31.07.2020), в которых говорится о том, что не отчуждаются земли особо охраняемых природных территорий ,в которые включаются и земли национальных парков.

Возникает необходимость, в корректировке данной статьи для соответствия происходящим законодательным изменениям.

Не смотря на выявленные недочеты допущенные законодателем, данный Федеральный закон во многом улучил положение граждан.

Так, до введения закона граждане не могли в полной мере реализовывать свои права в отношении земельного участка, находящегося на территории национальных парков, теперь же они могут осуществлять на своем земельном участке строительство, садоводство и многое другое, что раньше было запрещено законодателем .

Органы местного самоуправления также получили возможность в полном объеме воплотить программы социально-экономического развития данного муниципального образования, расположенного на территории национальных парков и возможность проводить мероприятия по созданию благоприятных условий жизнеобеспечения граждан , в частности, на социальную поддержку населения.

Федеральным законом "О внесении изменений в Федеральный закон "Об особо охраняемых природных территориях" и отдельные законодательные акты Российской Федерации" у граждан также появилась возможность законно отстаивать свои права касающиеся принадлежащих им земельных участков, на территориях национальных парков в судебном порядке ,поскольку до введения данного закона действия суда по защите прав граждан во многом ограничивались законом, по этому поводу существовали серьезные конфликты и напряженность среди граждан, проживающих на данных территориях.

1. Федеральный закон от 30 декабря 2020 г. N 505-Ф3 "О внесении изменений в Федеральный закон "Об особо охраняемых природных территориях" и отдельные законодательные акты Российской Федерации"// Российская газета, № 2(8353), 12.01.2012.

2. Градостроительный кодекс Российской Федерации // Собрание законодательства Российской Федерации, 2005, № 31, ст. 5013, 5023.

3. Федеральный закон от 13.07.2015 N 218-Ф3 (ред. от 30.12.2020) "О государственной регистрации недвижимости" (с изм. и доп., вступ. в силу с 23.03.2021) // Собрание законодательства Российской Федерации, 2019, № 29, ст. 3861.

4. Федеральный закон "О приватизации государственного и муниципального имущества" от 21.12.2001 N 178-Ф3 (ред. от 31.07.2020 N 293-Ф3) // Российская газета, № 2884, 26.01.2002.

5. Причины возникновения социальной напряженности в населенных пунктах, расположенных в границах национальных парков, и принимаемые меры по ее снижению. М.В. Басова // Юридические науки, № 49 , 2020, с.6-10.

6. Колиева А.Э. Проблемы возмещения государством вреда, причиненного при отправлении правосудия. // Вестник Северо-Осетинского государственного университета имени К.Л.Хетагурова. № 1. 2009. С.97.

7. Земельный кодекс Российской Федерации: Федеральный закон №136 (ред. от 20.04.2021) // режим доступа СПС «КонсультантПлюс».

8. Колиева А.Э. Проблемы возмещения имущественного вреда // Вестник Краснодарского университета МВД. 2010. №3. С.28. 